v. 9, n.4

Vitória-ES, Oct.-Dec 2012

p. 127-150 ISSN 1808-2386 DOI:http://dx.doi.org/10.15728/bbr.2012.9.4.6

\title{
Why do buyers complain about online purchases?
}

\author{
Luis Fernando Hor-Meyll ${ }^{\dagger}$ \\ PUC-RJ \\ Marcelo Barreiros Barreto ${ }^{\Omega}$ \\ Marketing Analyst at OI Telecomunicações \\ Marie Agnes Chauvel (in memoriam) \\ Federal University of São João Del Rei \\ Fábio Francisco de Araujo ${ }^{ \pm}$ \\ $P U C-R J$
}

\begin{abstract}
Consumers who make purchases in online channels do not feel fully satisfied and complaints on different stages of the service are frequent. To identify motives for such complaints, 720 communications, posted in one-year period on the main Brazilian website for complaints and addressed to the three online retailers who received most complaints, were randomly selected and submitted to content analysis. Results reveal the most frequent motives for complaints by online consumers: failures in after-sale service, delays and failures in deliveries and failures related to the policies of exchange and return. The method used in this work and the results obtained are a relevant contribution to the literature on the subject. Thanks to its simplicity and low cost of application, the method can easily be used by companies to reveal motives of dissatisfaction of consumers with online channels, offering elements to improve processes.
\end{abstract}

Key words: Online complaints; dissatisfaction; online purchases.

Received 04/02/2012; revised 07/09/2012; accepted 07/16/2012; published 11/16/2012.

*Corresponding authors:

${ }^{\dagger} \mathrm{PhD}$ in Administration at COPPEAD/ UFRJ

Affiliation: Assistant Professor at IAG/PUC-RJ

Address: Rua Marques de São

Vicente no. 225

Rio de Janeiro - RJ -

Brazil

E-mail: hormeyll@iag.puc-

rio.br

Telephone: (21) 2138-9201

$\Omega$ Master's degree in Administration at IAG/PUCRJ.

Affiliation: Marketing Analyst at OI Telecomunicações Address Rua São Clemente no. 243 casa 4

Rio de Janeiro - RJ - Brazil

E-mail: mbbarreto@gmail.com

Telephone: (21) 9417-0779
${ }^{\ddagger} \mathrm{PhD}$ in Administration at COPPEAD/ UFRJ Affiliation: Assistant Professor at the Federal University of São João Del Rei.

\author{
$\uparrow$ Master's degree in \\ Administration at IAG/PUC-RJ \\ Affiliation: Student, the \\ Doctorate Program of \\ IAG/PUC-RJ \\ Address: Rua Marques de São \\ Vicente no. 225 \\ Rio de Janeiro - RJ - Brazil \\ E-mail: \\ fabiofdearaujio@gmail.com \\ Telephone: (21) 2138-9201
}

Publisher's Note: This article was accepted by Bruno Funchal 


\section{INTRODUCTION}

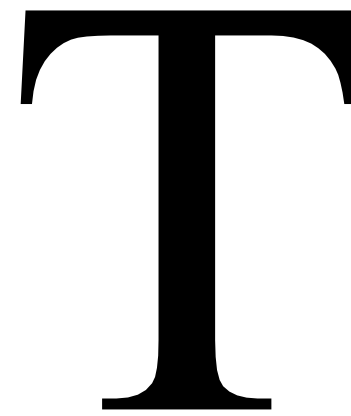

he internet transformed consumer relations: electronic commerce has provided retailers with a new business structure; for consumers, convenience, more products (not limited to physical spaces in stores), greater flexibility for off-store purchases and low search costs (ANDERSON, 2006). Its popularization has changed the form and speed of communication and interaction among persons, reducing distances and facilitating access to information (ARAUJO; CHAUVEL, 2007; LÉVY, 1997; SANTOS, 1996): the new opinion leaders are the consumers themselves, who publish reviews on what they purchase and record their opinions in blogs, websites and virtual communities, making them accessible to many and stimulating the exchange of information on companies, products and services (ANDERSON, 2006).

However, many consumers do not feel fully satisfied when purchasing online (HA; COGHILL, 2008). Complaints are frequent, and, just as they can unite to celebrate a brand, consumers exchange negative comments on the internet, a powerful vehicle to express dissatisfaction (GRÉGOIRE; TRIPP; LEGOUX, 2009; WARD; OSTROM, 2006), to the point of online complaints being considered a threat to companies (ARIELY, 2007; MCGREGOR, 2008). On the internet, the consumer can express opinions, becoming a generator of content and substantially expanding the power of word-of-mouth communication (DELLAROCAS, 2003).

The dissatisfaction has been considered as an individual experience, but there is evidence that, when dissatisfied consumers meet, the interaction strengthens the antipathy by the company that caused the dissatisfaction (WARD; OSTROM, 2006), with various websites which expose comments and complaints being created. Communities with scathing names (in Brazil, "I hate company X") have appeared in social networks or as independent websites (CHO et al., 2002).

Investigation of websites and virtual communities by means of non-intrusive observation allows companies to know the needs of their target demographic, extracting suggestions for the definition of strategies and for the development or modification of products and services (SCHIFFMAN; SHERMAN; COHN, 2008), a task which is difficult and costly to perform in traditional retail business. The sites dedicated to complaints contain spontaneous reports by consumers, which are useful to understand dissatisfaction with online transactions. 
Seeking to know the principal motives of dissatisfaction with online purchases, this exploratory study proposed to investigate testimonials of consumers in the main Brazilian website dedicated to complaints.

\section{DISSATISFACTION AND COMPLAINT}

Many studies on dissatisfaction are based on the Theory of Disconfirmation, which postulates that satisfaction and dissatisfaction result from comparison between an internal reference existing before the purchase and the result achieved (LEE; JOSHI, 2007). "The judgment of satisfaction is generally recognized as originating from comparison between the level of performance, quality and other effects perceived by the consumer of the product or service, with a standard of evaluation" (OLIVER; WESTBROOK, 1991, p.85). The consumer's expectation for the performance of the product or service before its acquisition is a central element of this process.

Expectations "create a reference framework from which a comparative judgment is made. Thus, results which are lower than expected (negative disconfirmation) are judged to be inferior to such point of reference, while better results (positive disconfirmation) are evaluated as superior" (OLIVER, 1980, p. 460- 461). Such model provides that "feelings of dissatisfaction occur when consumers compare their perceptions of performance of a product with their expectations" (SPRENG; MACKENZIE; OLSHAVSKY, 1996, p. 15).

Giese and Cote (2002), after summarizing more than 20 definitions of satisfaction, revealed that they had more trust in approaches based on affective responses of the consumer, as they allow the measurement of the satisfaction specific to a context, instead of using only disconfirmation. Oliver (1997) explained dissatisfaction as a judgment that a product or service, or some of their characteristics, generates a level of discomfort in the sensation of obtaining the expected benefits.

Kotler (1994) divided the possible actions by the dissatisfied consumer into two categories: "public" (complaint to the company, to public or private agencies, and legal actions to obtain reimbursement) and "private" (individual boycott of the manufacturer or resellers and word-of-mouth spreading of the negative experience).

Some authors (BLODGETT; WAKEFIELD; BARNES, 1995; SINGH; PANDYA, 1991) distinguish two categories of public actions: "direct action", i.e., complaint to the seller or producer, and "indirect action" (or "through third parties"), which involves complaint to public or private institutions, such as the Judiciary, newspapers and Procon (a public body for consumer protection and defense). Behaviors of abandonment of the 
supplier and negative word-of-mouth spreading seem to not have a linear relationship with the degree of dissatisfaction, but there is evidence of linearity in the case of direct actions (SINGH; PANDYA, 1991).

Although it occurs less frequently than direct action, indirect actions, especially in the online context, seems to be more harmful for companies than direct action, which, if well managed, allows the remedying of the problem and even reversion of the dissatisfaction, in addition to, by means of the complaint, providing information to correct problems (REICHHELD, 1996; WARD; OSTROM, 2006).

The propensity to complain is a measure of the inclination of the consumer to express dissatisfaction, when facing a purchase situation that was not satisfactory (BEARDEN; TEEL, 1983), and it seems to be related to the degree of dissatisfaction. However, some studies point to the influence of other factors, such as the type, complexity, life expectancy and price of the product acquired, the perception of probability of success of the action (BLODGETT; WAKEFIELD; BARNES, 1995), the consumer learning process and restrictions of time or resources (KOLODINSKY, 1995).

Not everyone complains when they are not satisfied (CHAUVEL, 2000; GRONHAUG, 1977). There are four standards of response to dissatisfaction: "angry" consumers complain, disparage the company and change suppliers; "activists" do not complain directly, but stop buying and promote negative word-of-mouth; "pacific" consumers do not take any action and do not abandon the company; those who "give a new chance" complain directly, they do not disparage the company and, in principle, they do not change suppliers (ZEITHAML; BITNER, 2003).

By complaining, consumers have high expectations and want their problem to be solved quickly, or to be compensated by the inconvenience. Above all, they expect complaints to be treated fairly (TAX; BROWN, 1998).

The Theory of Justice has received attention as a theoretical basis for studies related to the recovery of services (KUO; WU, 2012). It identifies three dimensions which influence satisfaction with the management of complaints: distributive justice, related to evaluation on the compensation received for the damage caused; procedural justice, related to procedures used to determine such compensation, in an objective and representative manner of the consumer's rights; and interactional justice, related to how the decision was communicated and the quality of the relations maintained during the process. (BLODGETT; WAKEFIELD; BARNES, 1995; DE RUYTER; WETZELS, 2000; HOFFMAN; KELLY, 2000; SANTOS; SINGH, 2003; TAX; BROWN, 1998). 
Several studies investigated relations between the dimensions of justice and satisfaction with the management of complaints (BLODGETT; WAKEFIELD; BARNES, 1995; DE RUYTER; WETZELS, 2000; HOFFMAN; KELLY, 2000; KUO; WU, 2012). In Brazil, Fonseca, Trez and Espartel (2005) found that the recovery effort, when perceived as satisfactory, causes positive effects on the company's evaluation. Farias and Santos (2000) observed that among the theories of performance, disconfirmation, justice and emotions, the theory of justice had the strongest effect on satisfaction, presenting higher impact than that observed in studies conducted in the USA.

The three dimensions of justice seem to exert positive effects on satisfaction with the management of complaints (CHAUVEL; GOULART, 2007; SANTOS; SINGH, 2003), which can be different in different cultures (SANTOS; FERNANDES, 2008). However, the perception of injustice can lead to negative feelings, leading the consumers to concrete actions (ALBUQUERQUE; PEREIRA; BELLINI, 2010), such as making public the break with the company through their online complaints (GRÉGOIRE; TRIPP; LEGOUX, 2009).

\section{SATISFACTION WITH ONLINE PURCHASES}

Regarding online purchases, Mckinney, Yoon and Zahed (2002) suggested that the difference between the consumer expectation and the website performance, and the information provided by the website will determine the satisfaction. Lee and Joshi (2007) expanded the definition of satisfaction as being an affective response based on the consumer's previous experiences with conventional stores and service meetings mediated by computer.

Massad, Heckman and Crowston (2006) developed taxonomy for the antecedents of satisfaction of the online buyer, which included failures in the service delivery, emotional states prior to the service meeting, characteristics and behaviors of the retailer's employees, the website interface and trust in the retailer.

Other studies examined different factors that would influence the satisfaction of the online consumer, such as the quality of the information provided, the quality of the website and of the service offered (MCKINNEY; YOON; ZAHEDI, 2002), convenience and pleasure in buying (LEE et al., 2003) and time and cost savings (MCKINNEY; YOON; ZAHEDI, 2002; KOHLI; DEVARAJ; MAHMOOD, 2004).

The online consumer's satisfaction can be affected by technological factors (which include security in transactions, usability of the website, privacy of personal data), by factors related to the purchasing process (convenience, trust in the retailer, satisfactory 
delivery service) and by factors related to the product (the goods themselves, value to the consumer and personalization of the offer) (SCHAUPP; BÉLANGER, 2005). These factors are presented in Table 1.

Table 1: Determinants of Satisfaction with Online Purchases

\begin{tabular}{|c|c|c|c|c|}
\hline CATEGORY & FACTOR & & ATTRIBUTES & \\
\hline \multirow{3}{*}{ TECHNOLOGY } & Security & Cryptography & $\begin{array}{l}\text { Accounts with } \\
\text { identity and } \\
\text { password }\end{array}$ & $\begin{array}{l}\text { Confirmation } \\
\text { screen of the order }\end{array}$ \\
\hline & Privacy & Privacy statement & $\begin{array}{l}\text { Policy on selling } \\
\text { information }\end{array}$ & Use of cookies \\
\hline & Usability & Friendly interface & $\begin{array}{l}\text { Adequate search } \\
\text { capacities }\end{array}$ & Interactive site \\
\hline \multirow{3}{*}{ PURCHASE } & Convenience & $\begin{array}{l}\text { Ease and pleasure in } \\
\text { buying }\end{array}$ & Post-sale service & $\begin{array}{l}\text { Comparison } \\
\text { among prices and } \\
\text { products }\end{array}$ \\
\hline & Trust & $\begin{array}{l}\text { Belief in the retailer } \\
\text { and in the system }\end{array}$ & $\begin{array}{l}\text { Reliability and } \\
\text { integrity }\end{array}$ & $\begin{array}{l}\text { Minimization of } \\
\text { concerns and } \\
\text { regrets }\end{array}$ \\
\hline & Delivery & $\begin{array}{l}\text { Minimization of the } \\
\text { delivery time }\end{array}$ & $\begin{array}{l}\text { Communication of } \\
\text { possible delays }\end{array}$ & $\begin{array}{l}\text { Tracking number } \\
\text { for the order }\end{array}$ \\
\hline \multirow{3}{*}{ PRODUCT } & Goods & Variety & Exclusive products & Seasonal products \\
\hline & Value & $\begin{array}{l}\text { Gratification of the } \\
\text { consumer }\end{array}$ & $\begin{array}{l}\text { Quality of the } \\
\text { product }\end{array}$ & Total cost \\
\hline & Personalization & $\begin{array}{l}\text { Possibility of } \\
\text { personalization }\end{array}$ & Online configuration & Quantity of options \\
\hline
\end{tabular}

Source: SCHAUPP; BÉLANGER, 2005, p. 101.

Technological factors are related to characteristics of the website, which should ensure functionality, security, privacy and intuitive and easy use. The purchase experience comprises trust, delivery times and perceptions and feelings during and after the purchase.

The consumer seeks the online environment to save time, thus convenience is paramount, including ease in finding the product, the time spent in the purchase, the pleasure in buying, the ease in comparing prices and post-sales services (SCHAUPP; BÉLANGER, 2005). Factors related to the product comprise quality, availability and possibilities of personalization. The product value represents a compromise among the sensation of post-purchase gratification, the quality perceived and the price paid (SCHAUPP; BÉLANGER, 2005).

Lee and Joshi (2007) considered that the majority of studies on the satisfaction of online consumers devoted much attention to technological aspects, relegating the importance of the service meeting to a secondary aspect. They developed a model of satisfaction with service encounters mediated by computer, involving factors such as (by 
order of importance) delivery performance, time savings, website functional properties, familiarity with the internet and low price. Aesthetic characteristics of the website, perceived risk, customer support and variety of products, however, did not prove to be significant.

Kim and Kim (2006) proposed a three dimensional model of satisfaction with online purchases that is summarized in Table 2 .

Table 2: Dimensions and Attributions of Satisfaction with Online Purchases

\begin{tabular}{ll}
\hline DIMENSION & ATTRIBUTE \\
\hline Eecurity & Clear information on cost and handling \\
& Purchase order notification \\
& Clear exchange policy \\
& Security in the transaction via Internet \\
& Appropriate handling and security of private information \\
& Detailed information on warranty \\
\hline Purchases at any time & Low price \\
& Good quality of images of the products \\
& Ease of using research tools \\
& Quick answers to customer questions \\
& Ease of browsing \\
& Status of the purchase \\
& Option of cancellation of purchase before finalizing the order \\
& Few clicks to find the product or information desired Updates \\
& of Web content \\
\hline Orfer information on the company (history, mission, etc) & Display the period of promotions \\
Show customer opinions on the products \\
Customer service \\
Size of photos of the appropriate products \\
Updates on new sections \\
Information on product care \\
Variety of products \\
\\
\hline
\end{tabular}

Source: KIM; KIM, 2006.

Thanks to data cryptography, consumers do not consider security in the transaction as the most important attribute (KIM; KIM, 2006). Kim and Kim (2006) concluded, as Schaupp and Bélanger (2005) did, that convenience is the most important aspect in the decision to purchase online, followed by trust in the retailer. Evaluations of customers who bought at the store that are published in the website, the history of the company, physical location, and volume of sales and number of customers serviced would be useful to create trust. 


\section{COMPLAINTS RELATED TO ONLINE PURCHASES}

A complaint occurs when a consumer expects a favorable event to occur and, instead of this, his/her expectations are frustrated (OLSHTAIN; WEINBACH, 1987). The expectations arise as a key element for the complaint behavior.

Cho et al. (2002) classified the expectations of the online consumer into five categories: in relation to the product; in relation to technology; in relation to the information made available; in relation to the online store; and in relation to conditions of sale through the website. The disconfirmation of any of the expectations would lead to dissatisfaction and to consequent complaints. Table 3 presents the results obtained by them.

Table 3: Causes of Complaints Related to Online Purchases

\begin{tabular}{llll}
\hline Origin of complaint & Category & Example of response & $\%$ \\
\hline $\begin{array}{l}\text { Customer Service (possibility of } \\
\text { contact, post-sale service, technical } \\
\text { support) }\end{array}$ & Online store & $\begin{array}{l}\text { Did not answer assistance requests, } \\
\text { waiting time longer than normal; non } \\
\text { cordial service }\end{array}$ & $33.8 \%$ \\
Product (quality, performance etc.) & Product & Product damaged or of low quality & $26.2 \%$ \\
Price & Product & Expensive; interest rate too high & $17.8 \%$ \\
Problems in delivery & Online store, sale & $\begin{array}{l}\text { Delivery time longer than promised, } \\
\text { shipping cost too high }\end{array}$ & $15 \%$ \\
conditions & Product was not as advertised & $2 \%$ \\
Questions of security and trust & Sale conditions & $\begin{array}{l}\text { Believing that the company exploits } \\
\text { people. }\end{array}$ & $1.9 \%$ \\
Following orders & & Site does not offer the order status. & $1.9 \%$ \\
\hline
\end{tabular}

Source: CHO et al., 2002, p.7.

The antecedents of satisfaction or dissatisfaction with online purchase can be classified into: (i) the decision to buy, when characteristics of the virtual store (technology, information made available on the website on products, exchange, return and safety policies, usability of the website, ease in placing the order) are critical; (ii) product delivery, which finalizes the transaction, and, differently from traditional retail, is subsequent to the purchase; (iii) post-sale service, which should resolve problems related to the product delivered and to associated services (CHO et al., 2002).

Kim et al. (2003) considered that the intention to complain would have three antecedents: (a) the attitude in relation to the behavior of complaining; (b) the perceived value of the complaint; and (c) the perception of the success of the complaint, which would mediate factors such as alienation, prior experience of complaining and controllability. 
Chang and Chin (2011) showed that the theories of Rational Action (FISHBEIN; AJZEN, 1975) and Planned Behavior (AJZEN, 1985) could explain the differences between consumers who complain to online retailers and those who complain to offline retailers. The former would better explain the variance in the intention to complain about offline retailers, while the latter would be more adequate to explain complaints to online retailers. Moreover, they showed that the attitude in relation to complaints and to subjective rules is less significant in the online environment than with offline retailers.

In general, complaints to an offline retailer are addressed to the person responsible for the act or situation that led to the dissatisfaction, a face-to-face action somehow involving a threat or embarrassment for the complainer (BROWN; LEVINSON, 1987). In this case, subjective rules can influence the intention to complain, which does not occur in the online environment (CHANG; CHIN, 2011).

To reduce the vulnerability of the complainer in face-to-face complaints, he/she uses more delicate or implicit forms of expression. On the internet, however, the complainer and the target of the complaint do not know each other and do not meet personally (VÁSQUEZ, 2011). As far as he/she is not exposed, the complainer does not need to be careful, and explicit and not very delicate forms of expression of feelings and outrage are very frequent (VÁSQUEZ, 2011). Moreover, the online complaint, although addressed to the entity responsible for the dissatisfaction, simultaneously reaches current or potential customers of the company about which the complaint is made, acting as a negative word-of-mouth communication (VÁSQUEZ, 2011).

\section{METHOD}

The website "Reclame Aqui" [Complain Here], the fourth largest site in number of comments on purchase experiences, only behind social networks (PORTAL EXAME, 2009; E-LIFE, 2008), was chosen to collect complaints relative to online purchases, due to the number of accesses (2.5 million monthly visits and 4,000 new daily complaints). Additionally, it is used exclusively as a channel to express dissatisfaction with purchases, while the others are social networks used with innumerable purposes, which could be problematic for data collection.

The three online retail companies with most complaints in the website in the month prior to data collection were taken into consideration. By then, the three held more than $55 \%$ of online retail sales (EBIT, 2012; B2W, 2012). To maintain anonymity, they are hereinafter referred to as companies A, B and C. Company A, perhaps due to the fact that it 
sells an exclusive line of products, had a higher frequency of complaints related to defects and low quality of products and to failures of technical support. Company B is the only one that offers an affiliation program, to encourage promotion in blogs and personal websites, which receive commissions for each purchase they generate. Company $\mathrm{C}$ is the only one which has extension of traditional retail operations to online retail, using online the same brand as its brick-and-mortar stores.

To avoid bias associated with periods associated to high-volume purchases (Christmas and Mother's Day are the most important dates for online retail in Brazil [EBIT, 2009]), complaints comprising a one-year period (those posted between January 1 and December 31) were collected. Over 7,000 complaints about transactions with the three companies were identified. To avoid that the number of complaints could make the treatment by analysis of content unviable, 20 complaints per month, for each retailer, were randomly selected, totaling 720 complaints.

On the site, the complaints, grouped by company, have a title, date of publication and city where the complainer lived. The complaints of each company were ordered chronologically, and a generator of random numbers was then used to draw the complaints. the numbers drew represented the position of the complaint within the monthly ordered list.

The content analysis followed the model of Thompson (1997), which allows the interpretation of textual data, and sought to group the complaints into categories based on the literature (CHO et al., 2002; KIM; KIM, 2006; LEE; JOSHI, 2006; SCHAUPP; BÉLANGER, 2005). However, to adequately portray the set of testimonials, it was necessary to create other categories. The procedure is justified because the analysis of content demands that one avoids abandoning elements not previously identified (FREITAS; CUNHA JR; MOSCAROLA, 1996).

The method presents some limitations: the quantity of comments may not contemplate all the motives of dissatisfaction of the consumers. Moreover, the manifestations studied are indirect public actions (BLODGETT; WAKEFIELD; BARNES, 1995; SINGH; PANDYA, 1991). Although there are, in the testimonials, mentions of complaints addressed directly to the company, their content is not known. Thus, the viewpoint studied was exclusively that of customers that resorted to indirect action, often because they were dissatisfied with the answers obtained in direct contact attempts. 


\section{RESULTS}

Each complaint contains at least one motive of dissatisfaction (category), but most cases indicated several motives, since the customer tends to describe a sequence of facts: they inform which was their first complaint and whether after the first dissatisfaction there were other disagreements with the company. Ten reasons for dissatisfaction were identified, shown in Table 1 sorted by the number of complaints. The first column shows the category of dissatisfaction and the following columns indicate in which complaint, by chronological order, the dissatisfaction was manifested. The last column totals the complaints per category.

Table 4: Category of dissatisfaction of the consumers with online purchases

1) Failure in post-purchase service

2) Failure in delivery of the order

3) Failure related to the policy of exchange and return

4) Defect in the product received

5) Discrepancy between what the website [sic] and what is delivered
6) Transaction not accepted
7) Failure of technical support
8) Delivery of the wrong product
9) Failure related to physical store service
10) Non-specific complaints

\begin{tabular}{|cccccccc}
$\mathbf{1}^{\text {st }}$ & $2^{\text {nd }}$ & $3^{\text {rd }}$ & $4^{\text {th }}$ & $\mathbf{5}^{\text {th }}$ & $\boldsymbol{6}^{\text {th }}$ & Total & $\%$ \\
54 & $\mathbf{2 0 6}$ & 53 & 8 & 1 & 0 & $\mathbf{3 2 2}$ & $\mathbf{2 5 , 6}$ \\
$\mathbf{2 5 6}$ & 10 & 2 & 1 & 1 & 0 & $\mathbf{2 7 0}$ & $\mathbf{2 1 , 5}$ \\
32 & 120 & 54 & 13 & 3 & 1 & $\mathbf{2 2 3}$ & $\mathbf{1 7 , 7}$ \\
121 & 4 & 3 & 1 & 0 & 0 & $\mathbf{1 2 9}$ & $\mathbf{1 0 , 3}$ \\
71 & 6 & 2 & 0 & 0 & 0 & $\mathbf{7 9}$ & $\mathbf{6 , 3}$ \\
63 & 7 & 0 & 0 & 0 & 0 & $\mathbf{7 0}$ & $\mathbf{5 , 6}$ \\
9 & 35 & 10 & 1 & 0 & 0 & $\mathbf{5 5}$ & $\mathbf{4 , 4}$ \\
28 & 2 & 1 & 0 & 0 & 0 & $\mathbf{3 1}$ & $\mathbf{2 , 5}$ \\
26 & 0 & 0 & 0 & 0 & 0 & $\mathbf{2 5}$ & $\mathbf{2 , 0}$ \\
53 & 0 & 0 & 0 & 0 & 0 & $\mathbf{5 3}$ & $\mathbf{4 , 2}$ \\
\hline
\end{tabular}

The analyses related to the categories of complaints are presented below:

\subsection{FAILURE IN AFTER-SALE SERVICE}

Related to failures in the customer-company interaction, it has the highest number of complaints (322). The highest incidence of dissatisfaction with the customer service occurs with failures in recovery after a previous interaction. Table 1 indicates 206 occurrences (64\% in the category) as the second complaint by the same customer. It appears that the customer initially complained about a problem with the order and, as he/she remained dissatisfied, the customer complained about the customer service itself.

The consumers became involved in public complaints when, after a service failure, there were failures in the attempts at recovery. The following complaint is illustrative: 
It has been over one month and I have not received the product and at each complaint I make to customer service, I always receive the same answer (we will call you and give up an update)... I returned the call and received the same excuse by the customer service representative (we will call you). Look, this is too much disregard for the consumer... my greatest sadness is for the lies that they tell....

The consumer seems to be indignant, feeling wronged by the little effort made to solve the problem and by the disregard of the employees hired (TAX; BROWN, 1998; WARD; OSTROM, 2006).

In some cases, despite the contact to report failure in the service, the customer may not demonstrate dissatisfaction. However, he/she expects the problem to be solved, or at least an effort to find a solution. Customers frequently complain about the lack of information, which generates even greater dissatisfaction. The lack of contact in return or the lack of a satisfactory solution are triggers for many complaints. The lack of answer to telephone contacts or to e-mails is interpreted as neglect:

... I am not able to solve this with the company neither by telephone nor by email. They do not answer e-mail, and, by telephone, they keep you on hold until the call is disconnected.

The comments of dissatisfaction suggest that the companies considered may be following a path opposite to that proposed by Chauvel and Goulart (2007), who stress the importance of the Customer Service "strictly respecting procedures, rules and deadlines informed to the customers... and to seek speed and efficiency in the treatment of the communications" (p. 8), as a way of answering satisfactorily. The high number of complaints corroborates the results obtained by Cho et al. (2002), who, in their "online store" category, identified the customer service as the most frequent cause of complaints (33.8\%). This type of complaint is related to procedural justice (procedures to determine compensation, in an objective manner which represents the consumer's rights) and interactional justice (form of communication of the decision and quality of relations maintained during the process), antecedents for dissatisfaction with the treatment of complaints (BLODGETT; WAKEFIELD; BARNES, 1995; DE RUYTER; WETZELS, 2000; HOFFMAN; KELLY, 2000; SANTOS; SINGH, 2003; TAX; BROWN, 1998).

The complaints seem to be triggered by faults in the channel of communication with customers. What seems to happen is that, going against expectations created by making the e-mail address and telephone number for contact available, the customer's request remains without any answer. As pointed out by Chauvel and Goulart (2007), 
negative answers must be communicated, so as to transmit transparency in the decision process.

\subsection{FAILURE IN DELIVERY OF THE ORDER}

The failure related to delivery seems to be the first reason to complain: 256 occurrences among 270, a result which exceeds that observed by Cho et al. (2002) (15\%). It is possible that this is due to logistical problems, caused by deficiencies of infrastructure associated with the Brazilian context.

With stores always "open", online retailers promise to eliminate barriers of time and location (ALBERTIN, 2000; ANDERSON, 2006) and to offer convenience (SZYMANSKI; HISE, 2000). The customer expected to be served with the promised readiness, and justifications for failures in delivery, in many cases, do not satisfy him/her. As far as it is the category that most leads to complaints, it has a considerable relationship with failure in post-purchase service: the customer dissatisfied with the deadlines not complied with has a good chance of complaining subsequently if his/her request is not met, or if he/she is treated differently than expected, receiving what is perceived as unfair treatment. Here the issue is distributive justice: with the failure of delivery, the consumer feels wronged, because he/she complied with his/her part of the transaction, but the company did not provide the relevant consideration for it (TAX; BROWN, 1998).

They have not delivered the product to me to date (...) they answer that the order has been with the carrier since the $4^{\text {th }}$, but what do I have to do with this? It does not interest me where it is or where it is not, what interests me is that the delivery is delayed.

Pires et al. (2004) showed that consumers fear suffering losses in the transaction, as the delivery is not made against payment. There is evidence that the perceived risk increases the dissatisfaction (CHO et al., 2003; GRONHAUG, 1977), thus, such type of failure is very detrimental, and may jeopardize trust.

\subsection{FAILURE RELATED TO THE POLICIES ON EXCHANGE ANDRETURN}

With 223 occurrences and ranking third in number of complaints, this complaint is classified under the "Security" category, which includes guarantee of secure purchases and the sensation of security in the process (KIM; KIM, 2006). The policy established in the websites of the companies studied is restrictive, in general, only allowing exchanges or returns within seven days after delivery. The application of this policy by online retailers is strict, and may generate dissatisfaction. 
I requested the exchange of the appliance and was informed that I should take it to a technical support center for the product to be repaired, how can I repair a product that I have not used yet??? I spoke to a customer service representative (the number was informed via e-mail) and she said that the procedure was to send it to technical support. I don't agree with this. I want a new one.

When the company accepts the exchange, the delay in picking up the product from the customer's home is a reason for complaint. Cases where the customer requests a return, but there is delay in picking up the product by an outsourced company, are common. The date for pick up, previously scheduled and not complied with, will lead the customer to contact the company again, and may be another issue for dissatisfaction.

The delay in picking up the product, for replacement or return, is understood differently by the customer and by the company. It is noticed from the complaints that there is divergence in the view of the parties: the customer considers that the process begins when the product is collected from his/her home. The retailer, in turn, considers that the process only begins when the product is entered into its inventory. This discrepancy seems to create in the customer a feeling of injustice, increasing dissatisfaction (TAX; BROWN, 1998).

There is also the option of the customer returning the product and requesting a reversal of the transaction. Some complain about not having received the reimbursement, despite the goods having already been picked up.

I asked for a reversal and nothing... Look, I've had it with you, I have just called the credit card administrator and they told me that you never reversed the value of any purchase to them. My name is BLACKLISTED, with SPC, SERASA [Credit Protection Agencies], the interests of the credit card go up, and up, and continue to go up.

There seems to be a difficulty that derives from the characteristics of online commerce. Differently from what occurs in physical stores, where terms for exchange or return may be verified simply and without ambiguity, there is dependence on outsourced companies, creating space for divergences, leaving customers even more insecure.

\subsection{DEFECTS IN THE PRODUCT RECEIVED}

Defects include scratches, dents or functional problems. With 121 occurrences, the category ranks second in the number of complaints in the first report, a result compatible with that obtained by Cho et al. (2002) (26.2\%). The data suggest that the solution to the problem may lead to more dissatisfaction, whether because of the policy on exchange, or the policy on return, or even because of the involvement of technical support. 
The machine which they delivered was faulty, I called them and they exchanged it. I didn't even use it. The new machine, with four months of use, had a fault on the drum.

The customer who receives a faulty product and wishes to replace it, and not a reversal of the amount, shall necessarily contact the company and wait even longer for a new delivery or the return of the technical support team. Not being responsible for what occurred and being penalized by the noncompliance with the initial sale conditions, he/she feels wronged and even more dissatisfied. Again, distributive justice is in question, because the customer believes that the company did not fulfill its part of the deal.

\subsection{DISCREPANCY BETWEEN WHAT IS SHOWN ON THE WEBSITE AND WHAT IS DELIVERED}

Ranking third in complaints in the first report (71 occurrences), this category answers for $2 \%$ of complaints in the study by Cho et al. (2002) and it is related to "accuracy of information" by Lee e Joshi (2006). One of the advantages of the internet is offering a larger quantity and better quality of information (SZYMANSKI; HISE, 2000). However, part of the complaints is related to differences of characteristics between the product advertised on the website and that delivered.

\footnotetext{
I bought a telephone... I needed to make a call using the speakerphone and I noticed that the product did not have this feature. I am absolutely sure that at the time of the purchase the description of the product in the Company's website stated that the model had speakerphone... checking the e-mail messages of confirmation of my order, sent by the Company (which e-mail I have with me and which was sent to the company), I noticed that the description of the product was that which I imagined.
}

In addition to error in the functionality of the product, the category includes errors in the quantity of the products purchased in relation to the quantity delivered. This may have occurred in promotions, in which an additional item would be included without monetary cost, but it was not delivered with the product. It is not possible to know whether the complaints derive from erroneous information or failure in the interpretation of the information on the website. The accuracy and clarity of the information provided seem to be a critical point to be examined with more attention by companies.

\subsection{TRANSACTION NOT ACCEPTED}

This fault, not mentioned in the literature, is ranked fourth in number of complaints in the first report (63 occurrences) and involves transactions in which, without the retailer informing a reason, the sale is not finalized and the transaction is terminated with a laconic 
message such as "it was not possible to complete the sale". This causes a feeling of rejection in the customer: he/she wants to buy, claims to have the money, but sees her/himself prevented from making the purchase, very often without an explanation. The discontent is manifested intensely.

This is pathetic, I want to buy and cannot do so because of the amateurism and irresponsibility of the company... How pathetic is this??? I want to buy and the company does not want to sell, is that it???

The most common cases concern credit card transactions, which may indicate that the payment was not approved. However, in some cases, the customer alleges to have available credit, and, even so, the transaction is not completed.

I made two purchases, in the total of six computers. The first on 03/19 was cancelled, I was not informed why and the second, on 03/20 number WEB13896746, cancelled after the debit on my statement (...). How can a purchase be debited on the credit card and cancelled for reasons not informed?

\subsection{FAILURES OF TECHNICAL SUPPORT}

55 occurrences were registered in this category. In chronological order, most complaints is preceded by another complaint, in general related to a product which had a defect after a few days of use. The customer, already dissatisfied with the defect, sought the retailer to obtain information on how to proceed. Cases where the customer received a poor service in the technical support stand out; or where the customer had to cover the costs to send the product to another state, because there was no technical support nearby; or where the customer complained about delay in the delivery of the product repaired or about the lack of information on terms, nature of the defect or the possibility of the repair being made.

[...] If I bought it, it is because I need it very much. I do not find it fair to pay a huge amount of money for a product and to be at the mercy of the authorized workshop or of the manufacturer.

When there is a fault in the technical support service, the image of the retailer is directly affected: for the customer, the seller is responsible, because it is the supplier or for not taking measures with the manufacturer to solve the problem.

I got in touch with the manufacturer and they gave me the address of the technical support to send the appliance, I got in touch with the technical support and was informed that they were no longer receiving appliances from the manufacturer. I called the company that supplied it and could no longer get in touch with the company (...). I contacted Procon and the Small Claims Court, and was instructed to file a lawsuit against the Supplier and against you (if the negotiation was not successful). Very well, I am getting in touch with you, to seek a solution to my problem which has already been going on for almost three months. 


\subsection{DELIVERY OF THE WRONG PRODUCT}

The frequency is low, although chronologically it is one of the customer's first complaints. Delivery of the wrong item also disrespects the agreement between the company and the customer (dimension "security" proposed by Kim and Kim [2006]), leading to more upset and a longer period for exchange.

I bought a washing machine on your Company's website, however, although the delivery was quick, they delivered to me a product with different characteristics than those stated in the order, i.e., I requested voltage $110 \mathrm{~V}$ and they delivered $220 \mathrm{~V}$.

\subsection{FAULT RELATED TO SERVICE PROVIDED BY THE PHYSICAL STORE OF THE RETAILER}

Only one of the companies studied has presence in traditional retail. Complaints that made reference to their physical stores, related to service, to the product, to warranty or to another aspect were categorized here by the association made by the consumers between the two channels, which work under the same brand. In the advertisements, the company encourages purchases on the Internet, in addition to having kiosks inside some stores which allow online purchases, which may lead the customer to imagine that operations are integrated. In the same way that clients of the physical store complain on the internet, it is possible that online consumers visit the nearest store to complain about online purchases, being even more dissatisfied if they do not have their requests answered.

Steinfield, Adelaar and Liu (2005) observed that companies that operate under the same name in the two channels were taking a long time to establish strategies which integrated operations. There are large retailers in the USA who allow a consumer to purchase a product online and pick it up from the most convenient physical store (STEINFIELD; ADELAAR; LIU, 2005), a convenience which could be extended to the process of exchange (category with a high index of complaint), perhaps eliminating an important source of discontent.

\subsection{UNSPECIFIC COMPLAINTS}

Comments not directly related to the purchase process were grouped here, such as complaints in relation to the price of the product on the website, demands for conditions to be maintained after the end of the promotion, complaints about the means of transport for delivery, complaints in which the customer only manifests his/her revolt, not making clear 
the motive of the dissatisfaction and offensive or inappropriate comments. With a small number of testimonials, it is not possible to reach significant conclusions from the analysis.

\section{FINAL CONSIDERATIONS AND RECOMMENDATIONS}

The results of this study, which investigated complaints of Brazilian consumers on a website dedicated to complaints, suggest that the principal motive of dissatisfaction with online purchases results from faults in post-sale service. Previous studies, conducted in other countries, obtained similar results (CHO et al., 2002). Most complaints reported occurred after consumers had sought to contact the company to solve a pre-existing problem. This fact is intriguing, because the performance of the Customer Service, which has the duty to focus on serving the customer, seems to be the target of most complaints, an important point which the method used evidences in a particularly clear manner.

What seems to occur is a growing dissatisfaction: the failure in post-sale service and, very often, the sensation for the customer that there was a communication breakdown, are added to the initial problem, which does not always trigger high levels of dissatisfaction. In online commerce, such occurrence has specially negative repercussions, as, because it is not possible to go to a physical store, the consumer feels "abandoned", which certainly generates anger and consequent desire of revenge to punish the damage (even if psychological) caused (GRÉGOIRE; FISCHER, 2006). It is essential that there is a communication channel which is appropriate to receive and deal with communications from customers, so that the consumer is not led to actions more harmful to the reputation of the organization.

Another important factor raised in this study is related to faults that occur in the delivery of the product, more frequent than that which was observed by Cho et al. (2002), involving three categories of complaint:

(i) The most frequent mention concerns delivery terms. This dissatisfaction represents the frustration with the loss of one of the main advantages perceived in online purchases- convenience. It is not by chance that fault in delivery is the main trigger of subsequent complaints on post-sale service. Lack of information and delay in rescheduling the delivery end up causing more dissatisfaction and compromising trust in the company. It is possible that this type of fault is a consequence of deficiencies of infrastructure associated with the Brazilian context, which suggests difficulties in operating and support structures. 
(ii) In the second category by order of frequency, there are complaints in connection with discrepancies between what is presented on the website and what is delivered, which were not mentioned frequently (2\%) in the study by Cho et al. (2002). New studies would be necessary to better understand their reasons, which could be related to the information supplied on the websites or their interpretation by buyers. The result reinforces the need, pointed out by Lee and Joshi (2006), to work with care on the accuracy of the information published,

(iii) A third group involves faults related to the policies on exchange and return, defects in the product and faults in technical support, problems already identified in previous studies (Cho et al. , [2002] found complaints motivated by problems related to the product and Kim and Kim [2006] included clarity of the policy on exchange as an attribute of the "security" dimension). What is noteworthy here is that such faults seem to trigger subsequent complaints, whose target is post-sale service. It should be noted that the categories 'defect in the product', 'delivery of wrong product' and 'discrepancy between what is presented on the site and what is delivered' have in common the need to activate processes of exchange and return, origin of a large number of complaints. Associated to security, the subject deserves more attention on the part of companies, since one single negative experience can compromise the feeling of security of the customer, developed during various successful transactions.

\subsection{LIMITATIONS AND RECOMMENDATIONS FOR FUTURESTUDIES}

It is important to note that this study examined only a small set of complaints, covering the period of one year. Moreover, the analyses conducted must be understood as appropriate to the companies studied, all large size companies, there being no bases allowing their generalization, whether for other companies of the same size or, specifically, for smaller companies. Future studies may be conducted, using the same method, to seek possible differences in the motivations of complaints in relation to smaller companies, or in more specific retail sectors.

\subsection{RECOMMENDATIONS TO MANAGERS AND COMPANIES}

Although most of the categories revealed contain complaints on errors which could be deemed as predictable, perhaps the managers of the companies studied do not have a clear understanding of the amplitude of the problems and of their impact on the image and 
credibility of the brand. Perhaps, for them, it is not clear that the feeling of rage generated in the consumer who feels wronged takes time to dissipate. Or worse, customers until then loyal to the company, with a long history of commercial relationship, are those that will maintain such feeling of rage for the longest period, because they feel more betrayed when they do not receive adequate recovery of the service (GRÉGOIRE; TRIPP; LEGOUX, 2009).

The wide vision that the methodological approach used allows, with the possibility of quantifying complaints by categories and of identifying the chronology of problems, enables corrective actions to be prioritized to eliminate more basic faults, that end up by originating a long chain of dissatisfaction and complaints and considerably damaging the company's image, including with its most precious customers - those who were until then loyal.

\section{REFERENCES}

AJZEN, I. From intention to action: a theory of planned behavior. In: Kuhl, J. \& Beckman, J. (Ed.). Action-control: from cognition to behavior. Heidelberg: Springer, 1985.

ALBERTIN, A. L. O comércio eletrônico evolui e consolida-se no mercado brasileiro. Revista da Administração de Empresas, v. 40, n. 4, p. 94-102, 2000.

ALBUQUERQUE, F. F.; PEREIRA, R. C.; BELLINI, C. G. Do repertório de comportamentos anticonsumo: retaliação e vingança no ciberespaço. In: ENCONTRO DE MARKETING DA ASSOCIAÇÃO NACIONAL DE PÓS-GRADUAÇÃO E PESQUISA EM ADMINISTRAÇÃO, 4., 2010, Florianópolis. Anais... Florianópolis: ANPAD, 2010.

ANDERSON, C. A cauda longa: do mercado de massa para o mercado de nicho. Rio de Janeiro: Elsevier, 2006.

ARAUJO, F. F; CHAUVEL, M. A. Estratégias de lançamento de filmes europeus no mercado brasileiro: um estudo de caso numa distribuidora independente. In: ENCONTRO NACIONAL DA ASSOCIAÇÃO NACIONAL DE PÓS-GRADUAÇÃO E PESQUISA EM ADMINISTRAÇÃO, 31., 2007, Rio de Janeiro. Anais... Rio de Janeiro: ANPAD, 2007.

ARIELY, Dan. The customers' revenge: HBR case study. Harvard Business Review, v. 85, p. 31-42, dez. 2007.

B2W. Disponível em:

<http://www.b2winc.com/upload/comunicadosaomercado/00000125.pdf $>$. Acesso em: 25/06/2012.

BEARDEN, W. O; TEEL, J. E. Selected determinants of consumer satisfaction and complaint reports. Journal of Marketing Research, v. 20, n. 1, p. 21-28, fev. 1983. 
BLODGETT, J. G.; WAKEFIELD, K. L.; BARNES, J. H. The effects of customer service on consumer complaining behavior. Journal of Services Marketing, v. 9, n. 4, p. 31-42, 1995.

BROADBRIDGE, A; MARSHALL, J. Consumer complaint behavior: the case of electrical goods. International Journal of Retail e Distribution Management, v. 23, n. 9, p. 8-18, 1995.

BROWN, P.; LEVINSON, S. Politeness: some universals in language use. Cambridge: Cambridge University Press, 1987.

CHANG, C-C.; CHIN, T-C. Comparing consumer complaint responses to online and offline environment. Internet Research, v. 21, n. 2, p. 124-137, 2011.

CHAUVEL, M. A. Consumidores insatisfeitos: uma oportunidade para as empresas. Rio de Janeiro: Mauad, 2000.

CHAUVEL, M. A.; GOULART, V. Como gerar valor para os clientes por meio dos serviços de atendimento ao consumidor: o que mostram as pesquisas. Cadernos EBAPE, v. 5, n. 4, p.1-16, 2007.

$\mathrm{CHO}$, Y. et al. An analysis of online customer complaints: implications for web complaint management. In: ANNUAL HAWAII INTERNATIONAL CONFERENCE ON SYSTEM SCIENCES, 35., 2002, Big Island. Proceedings... Big Island, Hawaii: HICSS'02, v. 7 , 2002.

$\mathrm{CHO}$, Y. et al. The impact of product category on customer dissatisfaction in cyberspace.

Business Process Management Journal, v. 9, n. 5, p. 635-651, 2003.

DELLAROCAS, C. The digitalization of word of mouth: promise and challenges of online feedback mechanisms. Management Science, v. 49, n. 10, p. 1407-1424, 2003.

DE RUYTER, K; WETZELS, M. Customer equity considerations in service recovery: a cross-industry perspective. International Journal of Service Management, v. 11, n. 1, p. 91-108, 2000.

E-BIT. Disponível em: 〈http://www.ebit.com.br/>. Acesso em: 10 ago. 2009.

. Balance of 2011 Brazilian e-commerce. Disponível em

〈http://www.webshoppers.com.br/webshoppers/WebShoppers25_English_final.pdf $\rangle$. Acesso em 25/06/2012.

E-LIFE. Disponível em: <http://elife.com.br/>. Acesso em: 17 dez. 2009.

FARIAS, S. A.; SANTOS, R. C. Modelagem de equações estruturais e satisfação do consumidor: uma investigação teórica e prática. Revista de Administração Contemporânea, v. 4, n. 3, p. 107-132, 2000.

FISHBEIN, M.; AJZEN, I. Belief, attitude, intention and behavior: an introduction to theory and research. Reading: Addison-Wesley, 1975. 
FONSECA, M. J; TREZ, G; ESPARTEL, L. B. O impacto das falhas e recuperação dos serviços na satisfação, lealdade e confiança. In: ENCONTRO NACIONAL DA ASSOCIAÇÃO NACIONAL DE PÓS-GRADUAÇÃO E PESQUISA EM ADMINISTRAÇÃO, 29., 2005, Rio de Janeiro. Anais... Rio de Janeiro: ANPAD, 2005.

FREITAS, H.; CUNHA JR., M. V. M; MOSCAROLA, J. Pelo resgate de alguns princípios da análise de conteúdo: aplicação prática qualitativa em marketing. In: ENCONTRO NACIONAL DA ASSOCIAÇÃO NACIONAL DE PÓS-GRADUAÇÃO E PESQUISA EM ADMINISTRAÇÃO, 20., 1996, Rio de Janeiro. Anais... Rio de Janeiro: ANPAD, 1996.

GIESE, J.; COTE, J. Defining consumer satisfaction. Academy of Marketing Science Review, 2000 (1). Disponível em: <http://www.amsreview.org/articles/giese01-2000.pdf >. Acesso em 25 jun. 2012

GRÉGOIRE, Y.; FISCHER, R. The effects of relationship quality on customer retaliation. Marketing Letters, v. 17, p. 31-46, jan. 2006.

GRÉGOIRE, Y.; TRIPP, T.; LEGOUX, R. When customer love turns into last hate: the effects of relationship strength and time on customer revenge and avoidance. Journal of Marketing, v. 73, n. 6, p. 18-32, nov. 2009.

GRONHAUG, K. Exploring consumer complaining behavior: a model and some empirical results. Advances in Consumer Research, v. 4, p.159-165, 1977.

HA, H., COGHILL, K. Online shoppers in Australia: dealing with problems. International Journal of Consumer Studies, v. 32, n. 1, p. 5-17, 2008.

HOFFMAN, K. D; KELLEY, S. W. Perceived justice needs and recovery evaluation: a contingency approach. European Journal of Marketing, v. 34, n. 3-4, p. 418-433, 2000.

KIM, K; KIM, E. Suggestions to enhance the cyber store customers' satisfaction. The Journal of American Academy of Business, v. 9, n. 1, p. 233-240, 2006.

KOHLI, R.; DEVARAJ, S.; MAHAMOOD, A. Understanding determinants of online consumer satisfaction: a decision process perspective. Journal of Management

Information Systems, v. 21, n. 1, p. 115-135, 2004.

KOLODINSKY, J. Usefulness of economics in explaining consumer complaints. The Journal of Consumer Affairs, v. 29, n. 1, p. 29-54, summer 1995.

KOTLER, P. Analyzing consumer markets and buyer behavior. In: Marketing management. 8. ed. São Paulo: Prentice Hall, 1994.

KUO, Y-F.; WU, C-M. Satisfaction and post-purchase intentions with service recovery of online shopping websites: perspectives on perceived justice and emotions. International Journal of Information Management, v. 32, n. 2, p. 127-138, abr. 2012.

LEE, K; JOSHI, K. An empirical investigation of customer satisfaction with technology mediated service encounters in the context of online shopping. Journal of Tchnology Management, v. 18, n. 2, p. 18-37, 2007. 
LEE, J. et al. The contribution of commitment value in internet commerce: an empirical investigation. Journal of the Association for Information Systems, v. 4, n. 1, p. 39-64, 2003.

LÉVY, P. L'intelligence collective: pour une anthropologie du cyberspace. Paris: La Découverte, 1997.

MASSAD, N.; HECKMAN, R.; CROWSTON, K. Customer satisfaction with electronic service encounter. International Journal of Electronic Commerce, v. 10, n. 4, p. 73-104, 2006.

MCGREGOR, Jena. Consumer vigilantes. BusinessWeek, n. 3, p. 37-58, mar. 2008.

MCKINNEY, V.; YOON, K.; ZAHEDI, F. The measurement of web-customer satisfaction: an expectation and disconfirmation approach. Information System Research, v. 13, n. 3, p. 296-315, 2002.

OLIVER, R. L. Satisfaction: a behavioral perspective on the consumer. New York: McGraw-Hill, 1997.

A cognitive model of the antecedents and consequences of satisfaction decisions.

Journal of Marketing Research, v. 17, n. 4, p. 460-469, nov. 1980.

OLIVER, R. L.; WESTBROOK, R. A. The dimensionality of consumption emotion patterns and consumer satisfaction. Journal of Consumer Research, v. 18, n. 1, p. 84-91, jun. 1991.

OLSHTAIN, E.; WEINBACH, L. Complaints: a study of speech act behavior among native and nonnative speakers of Hebrew. In: VERSHUEREN, J.; BERTUCCELLI-PAPI, M (Ed.). The pragmatic perspective: selected papers from the 1985 international pragmatics conference (Pragmatics and Beyond Companion Series, 5). Amsterdam: Benjamins, 1987. p. 195-208.

PIRES, G.; STANTON, J.; ECKFORD, A. Influences on the perceived risk of purchasing online. Journal of Consumer Behaviour, v. 4, n. 2, p. 118-133, 2004.

PORTAL EXAME. Disponível em: 〈http://www.portalexame.com.br>. Acesso em: 31 ago. 2009.

RECLAME AQUI. Consumidores expõem suas reclamações. Disponível em: 〈http://www.reclameaqui.com.br>. Acesso em: 10 ago. 2009.

REICHHELD, F. F. Learning from customer defections. Harvard Business Review, v. 74, n. 2, p. 56, mar. 1996.

SANTOS, C. P; FERNANDES, D. V. H. A recuperação de serviços como ferramenta de relacionamento: seu impacto na confiança e lealdade dos clientes. Revista de Administração de Empresas, v. 48, p. n. 1, p. 10-24, jan./mar. 2008.

SANTOS, C. P.; SINGH, J. Fairness in complaint handling: exploring a cross-cultural perspective. In: ENCONTRO NACIONAL DA ASSOCIAÇÃO NACIONAL DE PÓS- 
GRADUAÇÃO E PESQUISA EM ADMINISTRAÇÃO, 17., 2003, Atibaia. Anais... Atibaia: ANPAD, 2003.

SANTOS, M. A natureza do espaço: técnica e tempo: razão e emoção. São Paulo: Hucitec, 1996.

SCHAUPP, L. C.; BÉLANGER, F. A. Conjoint analysis of online consumer satisfaction. Journal of Electronic Commerce Research, v. 6, n. 2, p. 95-111, 2005.

SCHIFFMAN, L.; SHERMAN, E.; COHN, D. "Looking-In" on global consumer-users: to develop better product feature sets. In: EVOLUTION AND REVOLUTION IN THE GLOBAL KNOWLEDGE ECONOMY: ENHANCING INNOVATION AND COMPETITIVENESS WORLDWIDE, 10., 2008, Madrid. Proceedings... Madrid: Global Business and Technology Association (GBATA), 2008. p. 1012-1019.

SINGH, J; PANDYA, S. Exploring the effects of consumers: dissatisfaction on complaint behaviors. European Journal of Marketing, v. 25, n. 9, p. 7-21, 1991.

SPRENG, R.A; MACKENZIE, S.B; OLSHAVSKY, R.W. A reexamination of the determinants of consumer satisfaction. Journal of Marketing, v. 60, n. 3, p. 15-32, jul.1996.

STEINFIELD, C.; ADELAAR, T.; LIU, F. Click and mortar strategies viewed from the web: a content analysis of features illustrating integration between retailer's online and offline presence. Electronic Markets, v. 15, n. 3, p. 199-212, 2005.

SZYMANSKI, D.; HISE, R. E-satisfaction: an initial examination. Journal of Retailing, v. 76, n. 3, p. 309-322, 2000.

TAX, S. S.; BROWN, S. W. Recovering and learning from service failure. Sloan Management Review, v. 40, n. 1, p. 75-88, fall 1998.

THOMPSON, C. J. Interpreting consumers: a hermeneutical framework for deriving marketing insights from the texts of consumers consumption stories. Journal of Marketing Research, v. 34, n. 4, p. 438-455, nov. 1997.

VÁSQUEZ, C. Complaints online: the case of TripAdvisor. Journal of Pragmatics, v. 43, n. 6, p. 1707-1717, maio 2011.

WARD, J.; OSTROM, A. Complaining to the masses: the role of protest framing in customer-created complaint web sites. Journal of Consumer Research, v. 33, n. 2, p. 220-230, jul. 2006.

ZEITHAML, V.; BITNER, M. J. Marketing de serviços: a empresa com foco no cliente. Porto Alegre: Bookman, 2003. 